\title{
Implementing POWER Strategy Combined with The Animated Film to Improve The Writing Ability in Narrative Text for Junior High School
}

\author{
Muhari $^{1)^{*}}$, Utami Widiati ${ }^{2)}$, Furaidah $^{2)}$ \\ ${ }^{1)}$ SMPS Kartika Kendari-Southeast Sulawesi \\ ${ }^{2)}$ English Language Education-Universitas Negeri Malang \\ Jl. Palapa No. 8 Kendari. E-mail: muhari.english07@gmail.com*
}

\begin{abstract}
This study aimed to improve students' narrative writing by implementing POWER strategy combined with the animated film at class VIII of SMP. It was CAR design conducted in 2 cycles. The findings showed an improvement in writing ability in which 29 students achieved the minimum passing grade and the rest 6 students were in fair level of writing, and the result of teaching and learning process showed that $82.5 \%$ respond positively. The teachers are suggested to use this strategy as an alternative way to improve the writing ability and the media that is used should be appropriate with students' level.
\end{abstract}

Key Words: POWER strategy, animated film, writing narrative

\begin{abstract}
Abstrak: Penelitian ini bertujuan untuk meningkatkan kemampuan menulis naratif siswa dengan menerapkan POWER strategy berbantuan film animasi pada kelas VIII SMP. Penelitian tindakan kelas ini dilakukan 2 siklus. Temuan-temuan menunjukkan ada peningkatan kemampuan menulis dimana 29 siswa mencapai KKM dan sisanya 6 siswa berada pada tingkatan cukup dalam menulis, dan hasil proses belajar dan mengajar menunjukkan $82.5 \%$ merespon dengan positif. Guru disarankan untuk menggunakan strategi ini sebagai salah satu alternatif untuk meningkatkan kemampuan menulis dan media yang digunakan harus sesuai dengan tingkatan siswa.
\end{abstract}

Kata kunci: stategi POWER, film animasi, menulis naratif

One of the important basic language skills in English subject is writing. Writing is used to express ideas through written form. Besides that, writing plays in the last sequence after the other language skills, but it should not be underestimated (Seidhofer, 2005). As one of the language skills, writing has always occupied a place in most English language courses. Based on 2006 curriculum for Junior High School (SMP), students are supposed to master four English skills (listening, speaking, reading and writing). Among the four language skills, writing is usually considered as the most difficult to master (Widiati \& Cahyono, 2016). In writing skill, they are expected to be able to write several types of texts such as descriptive, procedure, recount, report and also narrative. Writing lesson has been seen as a boring, tiring, and difficult subject by the students. Most of the students have difficulties to follow the writing stages in their writing class. Based on the researcher's experience as an English teacher in SMPS Kartika Kendari, writing seemed to be a problem too. To know the ability of the students in writing narrative text, the researcher, and his colleague did preliminary study collaboratively. The preliminary study of this research was conducted through writing test, giving questionnaire and interviewing the teacher.

The writing test revealed that among 35 students in class VIIIB of SMPS Kartika Kendari, only 5 students got a score above 70 which means that only $14.28 \%$ passed the minimum passing grade (MPG), 8 students $(22.85 \%)$ were classified at a fair level, while 17 students $(48.57 \%)$ were classified at a poor level. Meanwhile, the rest, 5 students $(14.28 \%)$ were categorized at very poor level. The score of the writing test above indicated that there were several problems dealing with the students' writing abilities such as a problem in using grammar, organization of idea, 
content, vocabulary and also a mechanic. From the result of questionnaires, the writer found several problems related to writing ability. There were 15 students $(42.85 \%)$ who did not like writing activity, 33 students $(94,28 \%)$ thought that narrative writing was difficult, 30 students $(85.71 \%)$ did not feel confident with their narrative writing that they wrote. Moreover, 28 students ( $80 \%$ ) found it difficult to get and generate ideas in writing activity. The questionnaire also showed that 25 students $(71.42 \%)$ had difficulties in developing ideas in their writing, 26 students $(74.28 \%)$ had difficulties in dealing with the use of language features. Furthermore, 28 students $(80 \%)$ faced difficulties in dealing with the use of vocabulary. Meanwhile, 32 students $(91.42 \%)$ faced problems of using correct spelling, punctuation, capitalization in writing narrative text. From the result of the questionnaire, it can be concluded that most of the students do not like writing activities and they had difficulties to write in English. Based on the result of the interview with the teacher who taught there, she just gave tasks and students were asked to do the tasks such as the writing activities that just focused on rearranging words to be good sentences and rearranging sentences to become a good paragraph. It could not give stimulation towards students' thinking skill on how to organize ideas, how to put these ideas in their writing draft and its final product. In short, the strategy still did not match with the students' needs in overcoming the problem of writing.

Based on the facts stated above, the teacher needed variations in teaching writing. Thus, the researcher proposed a writing strategy namely POWER which stands for Prepare, Organize,Write, Edit, and Rewrite. Concerning the use of POWER strategy, it is necessary to be applied in teaching writing because it has some strengths. First, it helps the students to keep details in sequential order when they write something. According to Smith (2003, p. 20), before students start to write something, there must be a preparation. A good preparation will help the student to develop what they want to write in their draft of narrative such as telling who, what, when, where and why. Second, it can help the writer to organize the ideas during the process of writing because POWER strategy has some stages that make the writer easy to follow the steps in writing a text. Third, it can improve the writing quality. It means that the writer has more time to examine or recheck his/her piece of writing in terms of the use of correct grammar, the choice of word, punctuation, mechanic, etc. To monitor these aspects, it can be done by the writer themselves or from his/her peer (Harris, et al, 2006). To enable students to do self-monitoring and check their peers' work, the researcher will use the rubric as guidelines for them. The implementation of POWER strategy in teaching writing has been conducted by some researchers e.g. Airasian, 2000; Christopher, 2003, and Daniel, 2013. Those studies revealed that POWER Strategy could improve the writing ability in some aspects such as the organization of idea, content and also grammar.

Animated film is a medium that can be used to increase students' motivation in learning writing. The animated film is expected to be effective media for teaching narrative writing. There are some strengths of using animated film in teaching and learning process. Kenna, (2017); and Mayer \& Moreno, (2002) stated that with the use of animated videos or films in prewriting activity, students can explore the structural devices of the story (plotlines, character development, setting, and theme). It can be used as invaluable sources that could support children with contextualization in the language classroom (Brewster et al., 2002). Moreover, using animated film can be an entertaining and motivating tool also for learners with different skill level. Feger \& Thomas (2011) proposed that animated films constitute a unique teaching resource because the visualization creates, strong and lasting imagines concepts. So, the animated film is a media in teaching which also provides the learners with reallife language input.

This study applied POWER strategy combined with animated film and focused on students' narrative writing. Based on the statement above, it is hoped that POWER strategy combined with animated film can be helpful for teacher and students to reduce the students' problem in writing especially narrative text. Therefore, the researcher is interested in implementing POWER strategy combined with animated film to improve students' narrative writing ability in second-year grade of SMPS Kartika Kendari.

\section{METHOD}

The design of this study was Classroom Action Research (CAR). It was a research design used to improve the quality of teachers' in instruction as well as students' achievement in learning in the classroom. In this study, the researcher as the teacher in SMPS Kartika Kendari collaborated with his colleague to conduct Classroom Action Research that focused the implementation of POWER strategy combined with ani- 
mated film to solve the problems. By this research, the researcher applied POWER strategy combined with animated film to solve the students' problem dealing their narrative writing ability and to improve their classroom activities. The researcher himself carried out this study in the teaching process because he knew every single step in this strategy and was curious to see how this strategy could solve the students' problems. Meanwhile, the researcher asked an English teacher of SMPS Kartika Kendari as a collaborator so that they could learn together. The researcher acted as a teacher in the classroom while the collaborator helped the researcher to guide the students when they found difficulties in their activities. The collaborator also helped the researcher in observing the students' activities by using observation checklist and field note to gain data related to the criteria of success that had been set. The design of this research follows a model of CAR proposed by Kemmis \& Mc. Taggart (1988, p. 14) in Latief (2014, p. 144) that consisted of four steps: (1) planning, (2) implementing, (3) observing, and (4) reflecting. These four stages are preceded by the preliminary study.

The study consisted of two cycles. The targeted criteria of success had not all been achieved in the first cycle, so the researcher revised the planning for the next cycle The targeted criteria was achieved in the second cycle.

This research was carried out in Class VIIIB of SMPS Kartika Kendari in which this class has 35 students consisting of 10 male students and 25 female students. The implementation of POWER strategy combined with animated film was conducted in five meetings in the first cycle and three meetings in the second cycle. Furthermore, to assess the students' writing product, the researcher adopted the scoring rubric proposed by Jacob et al (1981). There were five components described in the analytical scoring rubric of writing: content, organization, vocabulary, language use, and mechanics.

In addition, the data were taken from the reflection about teaching and learning process conducted in the classroom. Firstly, the data described the students' attitude and perception toward the implementation of the teaching of narrative writing using POWER strategy combined with animated film. Secondly, the data described how the teacher conducted the teaching steps as planned in the lesson plans. To analyze whether the teaching process ran as planned, the researcher used the criteria proposed by Arikunto (2013).

There were five instruments used in this research. They were writing test, writing rubric, observation checklist, field notes, and questionnaire. The students' writing test was used to find out the improvement and achievement of the students in their writing ability as the result of the implementation of the strategy. The observation checklist was used to collect the data about the activities both the students and the teacher in the classroom. There were two kinds of instrument used for observation in this research namely observation checklist for classroom atmosphere and observation checklist for teaching and learning process. Meanwhile, field note was used to write anything related to the teacher and students' activities which are not stated in observation checklist. Furthermore, questionnaire was used to find out the students' interest and opinion on the implementation of POWER strategy combined with animated film.

\section{RESULTS}

\section{Students' Writing Achievement in $1^{\text {st }}$ Cycle}

In the first cycle, the students were asked to write a topic based on the animated film which entitles "Sleeping Beauty" by using their own words. They were asked to write the topic with length of 100 words minimally. The researcher checked the students' writing by using Jacob et al (1981) band score in term of content, organization, vocabulary, language use, and mechanics. The students' evaluation score in the first cycle could be seen in the Table 1 .

The data showed that the result of students' evaluation for the first cycle. Overall, the total score for content aspect was 668.5 , got the mean score 19.10

Table 1. Data Of Students' Evaluation Score In The First Cycle

\begin{tabular}{ccccccc}
\hline & \multicolumn{5}{c}{ Writing Aspects } & \multirow{2}{*}{ Total } \\
\cline { 2 - 6 } & Content & Organization & Vocabulary & Language Use & Mechanic & \\
\hline Min & 16 & 8.5 & 10 & 10.5 & 3 & 50.5 \\
Max & 23 & 19.5 & 21 & 21.5 & 5 & 88 \\
Total & 668.5 & 512 & 549 & 589 & 157 & 2476 \\
Mean & 19.10 & 14.63 & 15.69 & 16.84 & 4.49 & 70.74 \\
\hline Category & \multicolumn{7}{c}{70.74 (Fair) } \\
\hline
\end{tabular}


which was categorized as fair,then the total score of the organization aspect was 512 and got the mean score 14.63 which was categorized as good. While for vocabulary aspect, the total score was 549 and got mean score 15.69 which was categorized as good, the total score for language use aspect was 589.5 and got mean score 16.84 which was categorized as fair and the total score for a mechanic aspect was 157 and got mean score 4.49 which was categorized as good. The total score of these five aspects was 2476 which got the average mean 70.74 which was categorized fair. In addition to that, the minimum score was 50.5 and the maximum score was 88 . Most of the students get fair for content, organization, and vocabulary, while in language aspects were still poor category. From the table above we could state that there were 23 students $(65.71 \%)$ who passed the minimum score as the criteria of this study, while the rest there were 12 students $(34.29 \%)$ who did not pass the criteria. Even though their writing ability had already improved from the preliminary study until evaluation session in the first cycle, the target of this research had not been achieved.

\section{The Students' Improvement In Five Aspects Of Writing In The First Cycle}

After implementing POWER strategy combined with animated for group and individual in the first cycle, the students' writing ability had improved in five aspects of writing namely content, organization, vocabulary, language use and mechanic. The improvement from the preliminary study until the first cycle could be seen in the Figure 1. The diagram showed that there was an improvement in the first cycle toward the students mean score. Before applying POWER strategy combined with animated film, the students mean score for content aspect was 14.88 which categorized very poor and after implementing POWER strategy combined with animated film, it increased into 19.10 which was categorized fair. For organization aspect, it increased from 12.88 which was categorized fair to 14.63 which ws categorized well. For vocabulary aspect, it increased from 13.25 which were categorized fair to 15.69 which was categorized good. For language use aspect, it increased from 13.76 which was categorized fair to 16.84 which was categorized fair. Meanwhile, for mechanic aspect, it increased from 3.69 which categorized fair to 4.49 which categorized good. Based on the result of the students' writing in the first cycle, it could be seen that the mean score increased from a preliminary study that achieved 58.47 and it was categorized poor to 70.74 that was categorized as fair level. However, the percentage of the students who passed the criteria of success was $65.71 \%$. Since the target of the research that $75 \%$ should pass the criteria of success was not achieved, the second cycle needed to be carried out.

\section{Teaching And Learning Process In The First Cycle}

Based on the result of observation checklist and field note, there were some activities which were not implemented well and made the activities did not run optimally as planned in the lesson plans. The result of the observation checklist for classroom atmosphere could be seen in the Table 2 .

The table showed that in the first meeting the mean score of the activity was 19 with the percentage $47.50 \%$ of the whole activities that has been conducted in which was categorized fair, the mean score of the

Table 2. The Result Of Observation Checklist In The First Cycle

\begin{tabular}{ccc}
\hline Meeting & Mean Score & Percentage (\%) \\
\hline I & 19 & 47.50 \\
II & 21 & 52.50 \\
III & 23 & 57.50 \\
IV & 22 & 55.00 \\
V & 24 & 60.00 \\
\hline Total & \multicolumn{2}{c}{$\mathbf{1 0 9}$} \\
\hline Mean & $\mathbf{5 4 . 5 0}$ (Fair) \\
\hline
\end{tabular}

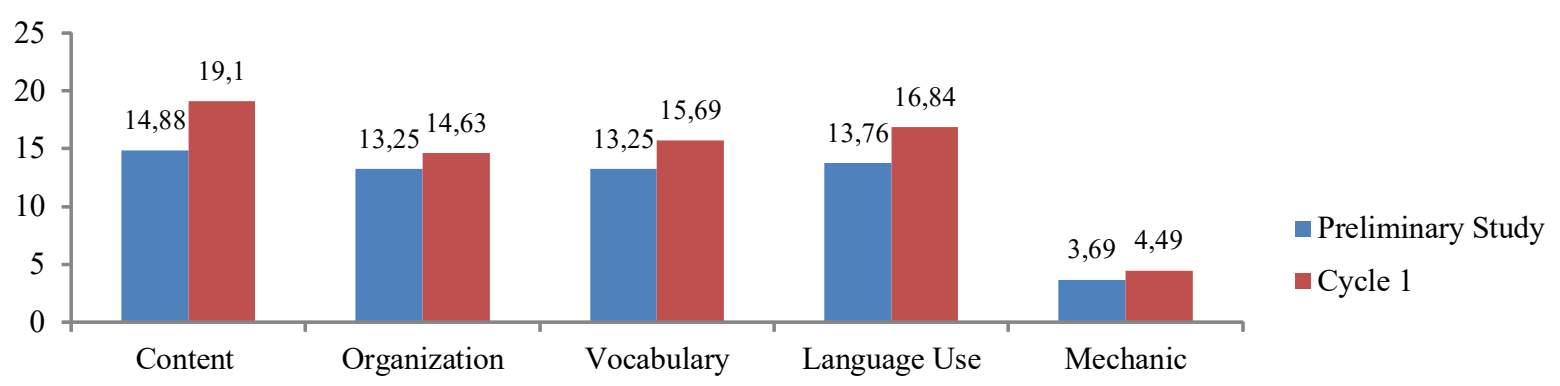

Figure 1. The Improvement Of The Students' Writing Ability In The First Cycle 
second meeting was 21 with the percentage $52.50 \%$ of the whole activities that has been conducted which belonged to fair category. For the third meeting, the mean score was 23 with the percentage $57.50 \%$ of the whole activities that has been conducted which belonged to fair category and for the fourth meeting the mean score was 22 with the percentage $55 \%$ of the whole activities in which categorized fair. Meanwhile, for the fifth meeting, the mean score was 24 with the percentage $60 \%$ which was categorized fair. Overall, those activities from the first meeting until fifth meeting the mean score were 109 with percentage $54.50 \%$ which categorized as a fair category. As stated in the criteria of the success of the research that the teacher and students' participation should achieve at least $80 \%$. In fact, the participation of the teacher and students in the first cycle just achieved $54.50 \%$, so that the next cycle needed to be conducted.

\section{Students' Writing Achievement In $2^{\text {nd }}$ Cycle}

In the second cycle, there were 35 students who attended the class and followed the evaluation session. The students were asked to write a topic which entitled "Beauty and The Beast" by using their own words. The students' writing achievement in this second cycle could be seen in the Table 3 .

The data above showed the result of students' evaluation for the second cycle. Overall, the total score was 771 and got the mean score 22.03 which was categorized as good, the total score of organization was 586 with the mean score 16.74 which was categorized as good, the total score of vocabulary was 609 with the mean score 17.40 which was categorized as good, the total score for language use was 672 and got mean score 19.20 which was categorized as good and for mechanic the total score was 169 with the mean score 4.83 which was categorized as good. The total score for the five aspects was 2807 and the mean score 80.20. This mean score was categorized as good writing ability. Then, the researcher concluded that the students' writing ability at class VIII.B had good writing quality in terms of content, organization, vocabulary, language use, and mechanic.

The result also showed that there were five students $(14.28 \%)$ who had very good achievement. twenty-four students $(68.57 \%)$ who had good to average achievement and the rest six students (17.15\%) who belonged to fair category. In this cycle no one got score which had been categorized poor and very poor. From the table above we could also see that there were 29 students $(82.85 \%)$ of the total students who passed the passing grade and the rest there were 6 students $(17.15 \%)$ who did not pass the passing grade but they were in a fair level of writing ability. In this cycle, the criteria of success were achieved from the result of the evaluation. So, the research was ended.

\section{The Students' Improvement In Five Aspects Of Writing In The Second Cycle}

After applying POWER strategy combined with animated film in teaching narrative writing for two cycles, the students' writing ability had improved. Their ability to produce a good quality of writing in term of content, organization, vocabulary, language use and mechanic were increased. Such improvement from the first cycle until the second cycle shown in the Figure 2 .

The Figure 2 showed that there was an improvement of the students' mean score in each cycle. Before applying POWER strategies combined with animated film, the students mean score for content aspect was 14.88 which was categorized very poor. Then after the implementation of POWER strategy combined with animated film in the first cycle. it increased into 19.10 which was categorized fair. Therefore, the second cycle was conducted. Then, at the end of the cycle, the students' mean score for content aspect increased become 22.03 which categorized good. Before applying POWER strategy combined with animated film student mean score for organization aspect was 12.88 which categorized fair. While after applying POWER strategy

Table 3. Data Of Students' Evaluation Score In The Second Cycle

\begin{tabular}{|c|c|c|c|c|c|c|}
\hline & \multicolumn{5}{|c|}{ Writing Aspects } & \multirow{2}{*}{ Total } \\
\hline & Content & Organization & Vocabulary & Language Use & Mechanic & \\
\hline Min & 17.5 & 11.5 & 14 & 13.5 & 4 & 65 \\
\hline Max & 26.5 & 20 & 21.5 & 22.5 & 5 & 92.5 \\
\hline Total & 771 & 586 & 609 & 672 & 169 & 2807 \\
\hline Mean & 22.03 & 16.74 & 17.40 & 19.20 & 4.83 & 80.20 \\
\hline Category & \multicolumn{6}{|c|}{80.20 (Good) } \\
\hline
\end{tabular}




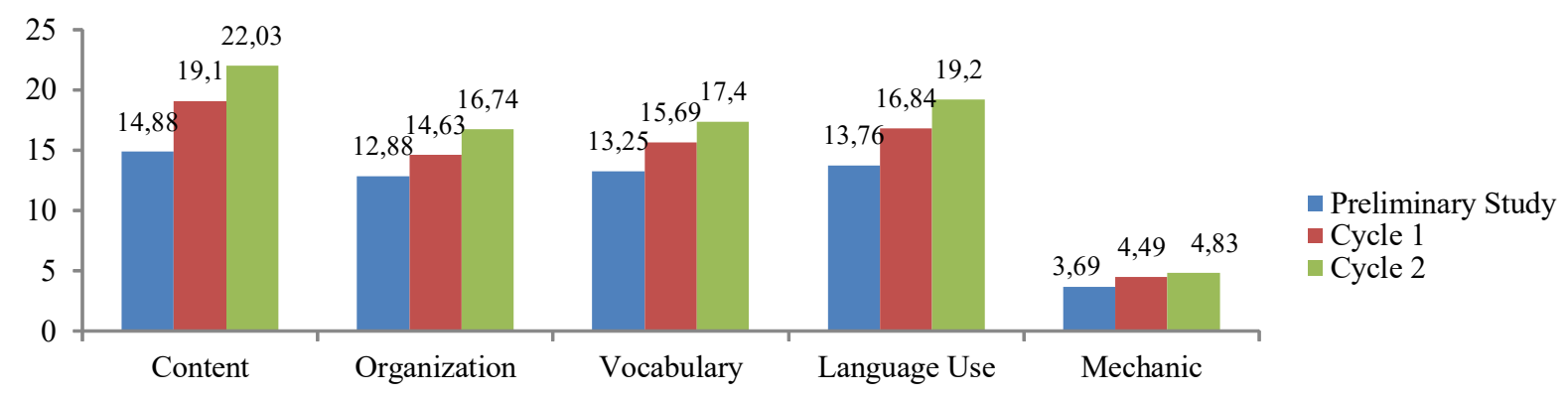

Figure 2. Students' Improvement In Five Aspects Of Writing In Second Cycle

combined with animated film in the first cycle, it increased into 14.63 which categorized good. At the end of the cycle, it increased become 16.74 which categorized good. Moreover, from vocabulary aspect, the mean score in the preliminary study was 13.25 which categorized fair.

After implementing POWER strategy combined with animated film, the mean score increased become 15.69 which categorized as good in the first cycle. In the second cycle, the mean score increased become 17.40 which also categorized good. In term of language aspect, before implementing POWER strategy combined with animated film the mean score was 13.76 which categorized fair. While after applying POWER strategy combined with animated film in the first cycle, it increased into 16.84 which categorized fair. At the end of the second cycle, it increased become 19.20 which categorized good. While in terms of mechanic the mean score in the preliminary study was 3.69 which categorized fair and it increased to become 4.49 in the first cycle and 4.83 in the second cycle which was categorized good.

Overall, the mean score of those five aspects in the preliminary was 58.47 that categorized poor while in the first cycle it increased into 70.74 that can be belonged to fair. Finally, in the second cycle the mean score increased into 80.20 that belonged to good category (Figure 3).

\section{The Teaching And Learning Process In $2^{\text {nd }}$ Cycle}

Based on the result of observation checklist in the second cycle, it showed the improvement of teacher and students' participation in teaching and learning process by using POWER strategy combined with animated film in the writing classroom activities, the result of observation checklist could be seen in the Table 4.

The table showed that in the first meeting the mean score of the activity was 31 or $77.50 \%$ of the activities in teaching and learning has been conducted as planned and it was categorized as good. The mean

\section{Table 4. The Result Of Observation} Checklist In The Second Cycle

\begin{tabular}{ccc}
\hline Meeting & Mean Score & Percentage (\%) \\
\hline I & 31 & 77.50 \\
II & 34 & 85 \\
III & 34 & 85 \\
\hline Total & \multicolumn{2}{c}{ 99 } \\
\hline Mean & \multicolumn{2}{c}{$\mathbf{8 2 . 5 0}$ (Fair) } \\
\hline
\end{tabular}

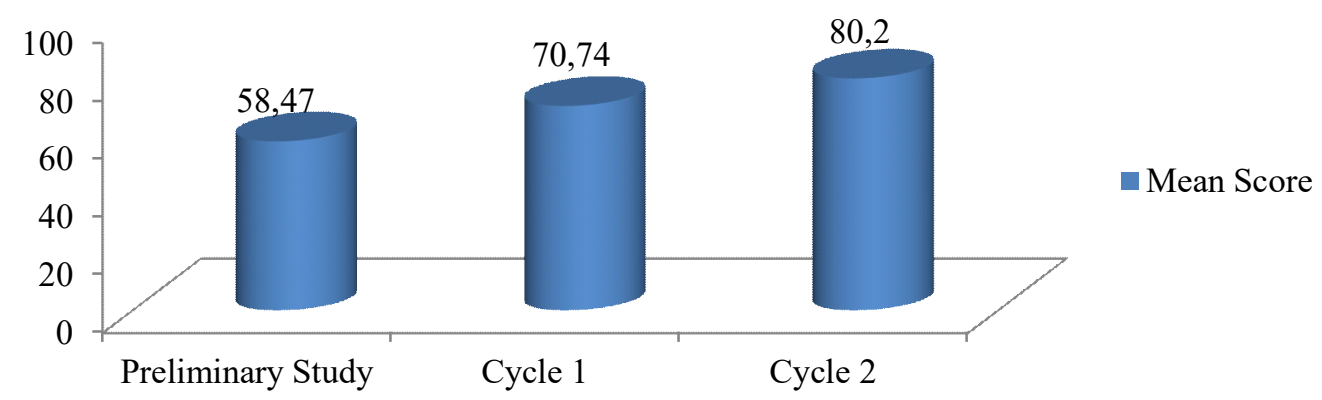

Figure 3. Students' Writing Ability Before And After The Treatment In Passing The Target Of The Research 
score of the second meeting was 34 with the percentage $85 \%$ of the activities in teaching and learning has been conducted and it was categorized very good. Meanwhile, for the third meeting, the mean score was 34 with the percentage $85 \%$ of the activities in teaching and learning has been conducted and it was categorized very good. Overall, those activities from the first meeting until third meeting the mean score was 99 with percentage $82.50 \%$ of the activities in teaching and learning has been run well and it was categorized as a very good category. As stated in the criteria of the success of the research that the teacher and students' participation should achieve at least $80 \%$ and the result of the second cycle had fulfilled the criteria of the research. Therefore, the cycle was ended.

\section{The Students' Response Of The Implementation Of POWER Strategy Combined With The Animated Film}

Based on the finding that had been elaborated in the previous section, it is acknowledged that POWER strategy combined with animated is appropriate in improving the ability of the students in writing a narrative paragraph. It is also effective to help the teacher and students in teaching and learning writing. It is supported by the result of questionnaire were $24(68.57 \%)$ out of 35 of the students strongly agreed and the rest 10 students $(28.57 \%)$ agreed that they were happy with the stage of POWER strategy in teaching writing, 25 students $(71.43 \%)$ strongly agreed and 10 students $(28.57 \%)$ agreed that they liked the implementation of POWER strategy combined with animated film as media in learning English, 18 students (51.43\%) strongly agreed and 17 students (48.57\%) agreed that the stages of POWER strategy combined with animated film could help them in writing narrative text well, 13 students $(37.14 \%)$ strongly agreed and 21 students $(60 \%)$ agreed that peer correction could help them to improve the quality of their writing, 15 students (42.86\%) strongly agreed and 20 students $(57.14 \%)$ agreed that the guiding question given by the teacher could help them in understanding the topic that they were going to write. In addition to that, there were 10 students $(28.57 \%)$ strongly agreed and 24 students (28.57\%) agreed they showed their high motivation to write using POWER strategy combined with animated film and 16 students (45.71\%) strongly agreed and 19 students (54.29\%) agreed that after implementing POWER strategy combined with animated film they could improve their ability in writing especially narrative text.

\section{DISCUSSION}

\section{The Students' Improvement in Writing Ability}

The implementation of POWER strategy combined with the animated film was successful in improving students' narrative writing. It could be seen from the result of this study in which the score of the preliminary study was 58.57 improved 70.74 in the first cycle and 80.20 in the second cycle. This result also was supported by the result of the teaching and learning process and students' response toward the implementation of the strategy. The data about teaching and learning procss showed that in first cycle the teacher and students did $54.50 \%$ of whole teaching and learning activities that were planned. In the second cycle $82.50 \%$ of the teaching and learning activities were accomplished. Meanwhile, the students' response toward this strategy confirmed that they liked this POWER strategy combined with the animated film. The criteria of success was fulfilled in the second cycle.

In the second cycle, most of the problems above could also be minimized by the teacher by providing more time in teaching and learning process, giving more language inputs (vocabulary and grammar), providing feedback, checking the students' understanding of their comprehensible input and also repeating the activities of the POWER strategy combined with the animated film which might increase the students' motivation in the teaching and learning process. POWER strategy could also affect the motivation and interest of students to write. The students' motivation and interest became two of the major effect that could influence the students' ability in writing a narrative paragraph. The application of POWER strategy showed that the students' motivation increased because the teacher prepared an engaging writing and enjoyable atmosphere when the process was going on. Harmer (2004, p. 62) argues that "An engaging writing task is one that involves students not just intellectually but emotionally as well; it amuses them, intrigues them or makes them feel good".

The result of the students' improvement through the implementation of POWER strategy is not different from the findings of some studies conducted by Fitria (2015); Daniel (2013), and Christopher (2003). Fitria 
(2015) implemented POWER strategy in writing ability of descriptive text to the tenth-grade students of SMA NU Al Ma'ruf Kudus in Academic Year 2014/2015. Her findings showed that this strategy was effective because the students could make descriptive text. They were active and enjoyable during the activities in teaching learning process. Daniel (2013) in his study used POWER strategy in teaching writing. The result showed that this strategy could improve the students' writing ability. Moreover, Christopher (2003) employed POWER strategy with quasi-experiment design in his study. The findings showed that there was an improvement in the students' writing ability after applying this strategy in some aspects such as content, organization, and grammar. Those studies had revealed that the POWER strategy can help students to solve the problem in their writing and increase the students' writing quality and motivation.

There are some considerations why the implementation of POWER strategy could improve the students' ability in writing the narrative. Firstly, the teacher helped students to be confident in writing, so they feel comfortable as writers. Secondly, the teacher gave necessary information to complete the task; the students need to understand clearly what the teacher wants them to do. Thirdly, the teacher prepared some suggestions when students got stuck. Those activities were done by the teacher automatically and could make the students more motivated to write their composition.

There are several strong possible explanations for the improvement found on the students' writing performance in the first and second cycle. In general, the improvement is probably caused by the animated films that was presented in the preparing stage of POWER strategy during the treatment session. The teacher provided this media as supplementary to support the implementation of POWER strategy. Moss (2010) states that the animation film in writing process can be used to organize or brainstorm the ideas session well. Similar to this, Lavery (2008) argues that film and video are effective ways in motivating and helping students to understand language. It can be said that animated film applied in learning English made a new atmosphere for students during teaching and learning process. By applying animated film in teaching writing, it could give the students opportunity to generate and explore their ideas naturally. Therefore, they could write narrative paragraph well based on the guidelines given. It also gave positive significant effect on the students writing ability.

\section{The Implementation of POWER Strategy Combined with the Animated Film}

The implementation of POWER strategy combined with the animated film was conducted in two cycles. The first cycle consisted of six meetings and the second cycle consisted of four meetings. In this implementation, POWER strategy was the main focus which consisted of five stages; prepare, organize, edit, and rewrite. The animated film was used as media to support the implementation of this strategy.

Prepare stage is one of the plans that should be done by the writers before they start to write something. To begin to write is apparently most of the students' problem. It is the matter of what to write and how to write it. One of the solutions to this problem is that the students should be guided in doing some activities which are usually called prewriting activities before coming to the actual writing. Preparing is an activity of prewriting that aims at helping the students to produce the ideas on a certain topic in the beginning of the writing process. According to Christenson (2002) prewriting involves everything the writer does before the beginning actual task of writing, including checking background knowledge, generating ideas and making plans for approaching the writing task. Similar to this, Wang (2014) states that in pre-writing the writers can brainstorm about the given topic which allows them to share ideas, learn from each other, and produce new ideas. Karim, et al (2016) affirm that through brainstorming activities, students can be guided to overcome some problems that they face in writing task.

In preparing stage of this study, the teacher provides some words list or vocabulary, guiding questions and grammar exercise which were related to the content of the animated story. To support the students in making composition correctly and clearly in English, they should be supported by the mastery of two main components of Language namely vocabulary and grammar. The wordlist is designed to make students focus on a particular set of vocabulary words might be a good way of developing the idea of noticing (Colgun, 2016). Several studies had also been conducted to discover the contribution of students' vocabulary toward their writing ability. Ali (2016), Cahyono \& Widiati (2015), McCutchen, et al (2014), Lesaux, et al (2014), Horst (2014), and Wilson (2014) found that vocabulary had an important role and provided the basis for developing students' ability in communicating both in spoken and written. In term of guiding questions, the students had the opportunity to answer and 
find out some information that existed in the animated film as a topic of their writing. Guiding questions aimed to develop students' critical thinking and to know their understanding of the animated film that they had watched. Raimes (1983) in Wulandari et al (2015) asserts that guiding question is used to allow the students a little freedom in structuring sentence in their writing activities. After the students got their topic, the teacher directed them to answer the questions given in the worksheet. This strategy was used to dig the students' understanding and knowledge about the topic in order to make it easier for them to develop their topic. The result showed that guiding questions given had affected the students' ability significantly in writing a narrative paragraph. Supporting this result, some researchers such as Mujiono, Widiati, and Iragiliati (2013), Ritonga (2015), Maulida (2016), and Wulandari. Raja \& Hasan (2015) revealed that guiding questions could improve the students' English skill in writing. Another research project which focused on implementing guiding question for writing skill was conducted by Mousa-Inaty (2015). He found that the majority of the student considered that guiding questions were useful in helping them to master the topic that was going to write.

Organizing is the second step of POWER strategy. It was focused on the outlining on what the students are going to write based on the topic. The purpose of organizing is to provide the learner with structural framework of information and helps to direct the learner's attention to the key concepts and conceptual relationship (Tayib, 2016). In line with this statement, Gregg \& Steinberg (2016, p. 14) states that the purpose of organizing process is to select the most useful of the materials retrieved by the generating process and organize them into a writing plan. In this study, the researcher employed the worksheet to the students in organizing their narrative writing. It focused on the generic structure of the narrative text namely orientation, complication, and resolution. The students were asked to organize and write the important things about their ideas that they had gotten from the animated film in the worksheet given. The worksheet is given to make students organize their ideas easily (Boumediance, Berrahal \& Harji, 2017). Recent research concerning the importance of organizing in writing activity had been highlighted in a range of studies (Gillespie, Olinghouse, \& Graham. 2013; Flores, 2015; Ningrum, Latief \& Sulistyo, 2016). They reported that organizing in writing process could enhance and strengthen the students' knowledge and understanding gotten from their information.
Organizing is also closely to the brainstorming and mind mapping activity. In this study, the students were asked to highlight the main important information of the plot of the story. According to Mohammad \& Hussein (2013) the writer can be motivated to do brainstorming to writing activities. Research evidence suggested that organizing, brainstorming the idea and mind mapping of the topic should be done in writing activities as part of motivating students to construct their writing in order ( Hashempour, Rostampour, \& Behjat, 2015; Manouchehry, Farangi, \& Qaviketf, 2014; Al-Shaer, 2014). From the explanation above, we can state that organizing in writing activity should be given to help the students to construct their composition in order based on the generic structure of any writing paragraph.

Developing writing is considered as the most difficult task for the writers as it involves many aspects of writing such as the content, the organization, the language use, the vocabulary, and the mechanic aspect (Widiati, 2016). Relating to the present study, the teacher led the students to write a rough draft by giving a model of how to order ideas they produced in prewriting (prepare and organize) activities to become a rough draft. Modeling was considered very important by the students since they did not know how to compose a good narrative paragraph in their writing. Previous research (e.g Chen, Zhang \& Yu, 2016; Limpo \& Alves, 2013; and Li, 2016) had indicated that modeling was beneficial to the students' conceptual development and help them to have a conceptual understanding of the task. Therefore, this study presented a model of narrative text at the first meeting in order that the students were familiar with the kind of this genre.

In writing activity, the teacher also guided the students to be able to write rough draft individually by asking them first to work in groups. In this study, the students worked in a group in the second meeting of the first cycle. After working with the group they would more confident in writing individually because they already had experience. The advantages of the working group are in line with the statement of $\operatorname{Ur}(1996$, p. 232) that the use of group improves learning outcomes, it also fosters learner responsibility and independence, can improve motivation and contribute to a feeling of cooperation and the warmth in the class. Moreover, Yazdi-Amirkhiz, Ajideh \& Leitner, 2016 found that group working reflects their role and promotes social interaction among the group members.

As presented in the previous part, the strategy used in this stage was peer editing. Brown (2001, p. 
353) stated that "peer editing is a true sharing process not only you get feedback from your classmates, but you also give feedback to them". Since the focus of this stage was mechanical aspects, the students were asked to exchange their drafts with their partner and asked to edit their friends' draft or even their draft in term of punctuation, spelling, capitalization, and grammar. Nevertheless, the teacher should explain, give examples of what and how to edit and even guide the students in editing. Through peer editing strategy, the students were motivated to learn the mechanical aspects in a good way. By having an understanding of it, the students could find or show the mechanical errors on their friends' draft or even their draft (Dirgeyasa, 2016). Moreover, by holding peer editing in order to edit the draft, the students could have a positive attitude and they could work together and tolerate each other when they have a different opinion (Khaki \& Biria, 2016). In addition, peer editing also can enhance the students' attitude to be more self-confident (Mac Arthur, Philippakos \& Ianetta, 2015).

Rewriting is the last step of POWER strategy that focused on the rewriting the final draft before it submitted to the teacher. The students were asked to pay attention to feedback and also a suggestion that had been done in editing stage. Arege (2015) argue that corrective feedback from the teacher can enhance the students' motivation in writing. It is obvious that the students found it easier to find as many as possible ideas, sentences, and words because the teacher prepared enough time and appropriate feedback during this research.

In terms of using the animated film in this study, the researcher presented it in preparing stage. In the first cycle, the use of the animated film was not implemented well because the researcher just played it once so that the students did not get the ideas optimally. In the second cycle, the animated film was played twice or three time. The repetition of playing the animated film was done to make students comprehend the story well and also to ensure them in getting more inputs. Even though the repetition of playing the animated film was done more than once, the students did not get bored because the film was authentic and interesting for them. The authenticity of the audiovisual media becomes the consideration that educators need to concern when applying technology into the classroom (Hasan \& Ahmed, 2016). For that reason, animation film is a medium that can be used to increase students' motivation in learning writing. There were five kinds of animated film that were used in this study. They were Red Riding Hood, Pinocchio, Sleeping Beauty, Rapunzel, and Beauty and The Beast. Those animated films were included fairy tales but it had different story or topic. The researcher gave three different topics in the first cycle; Red Riding Hood, Pinocchio and Sleeping Beauty. While in the second cycle it was used two different topics; Rapunzel and Beauty and The Beast. The topic was different to reduce the student's boredom in writing and to make the learning activities more interesting. All the animated film used English Language but they did not have subtitles on the screen. It had a purpose of encouraging the students' listening and visual ability in understanding the story.

Therefore, from the reasons above the researcher concluded that the implementation of POWER strategy combined with the animated film is successful to improve the students' ability in writing narrative text.

\section{CONCLUSSION}

Based on the findings, the implementation of POWER strategy combined with animated film could improve the students' narrative writing ability in terms of content, organization, vocabulary, language use, and mechanic. It can be seen in the students' first cycle which is 23 students $(65.71 \%)$ of the total students could achieve the minimum passing grade with the total mean score of those five aspects of writing found the mean score was 70.74. It was categorized as fair writing ability. Then in the second cycle, there was an improvement of the students writing ability which is 29 students $(82.85 \%)$ could achieve the minimum passing grade. The mean score of the second cycle was 80.20 which categorized as good writing ability.

The implementation of POWER strategy combined with the animated film that has improved the students' narrative writing ability in SMPS Kartika Kendari involved the following five procedures. They are preparing, organizing, wrting, editing and rewrting. In preparing steps, the activities involved as follows. 1) Asking the students to answer and discuss the diffi-cult words. Those words are related to the animated film which is given before they watch it. 2) Asking the students to do grammar exercise which related to the language features of narrative text. 3) Giving guiding questions which related to the animated film. 4) Asking the students to watch the animated film. 5) Asking the students to answer the guiding question given. 6) Asking the student to brainstorm and making list of important words based on guiding 
questions. In organizing steps, the activities involved as follows: asking the students to make the outline of the main idea in each paragraph and asking the student to organize the plot of the story based on the animated film. In writing step, the students are asked to write the draft based on the guidelines and notes from preparing and organizing steps. In editing stage, the students are asked to do peer editing based on the provided guidelines. Meanwhile, for rewriting step, it involved some activities such as: asking the students to rewrite based on the correction from their peer and feedback from their teacher and asking the student to submit their final writing.

The English teachers are suggested to use this strategy as an alternative way to improve the ability of the student in writing skill and the media that is used in teaching writing should be appropriate for the students' level and interest. Finally, for the next researcher who will conduct the same field of the study, it is recommended to use this study as an alternative reference in implementing the strategy in different skills or education level.

\section{REFERENCES}

Airasian. (2000). Guiding Students Writing Trough POWER strategy. Retrieved from http://www.sciencedirect. com/science/journal/10603743.

Ali, J. A. M. (2016). Investigating the Role of Vocabulary in Developing Writing Skills among the Students EFL (Unpublished doctoral dissertation). Sudan University of Science and Technology, Sudan.

Al-Shaer, I. M. (2014). Employing concept mapping as a pre-writing strategy to help EFL learners better generate argumentative compositions. International Journal for the Scholarship of Teaching and Learning, 8(2).

Arikunto, S. (2013). Prosedur Penelitian Suatu Pendekatan Praktik. Jakarta: Bumi Aksara.

Arege, J.B. (2015). The relationship between different methods of teacher correction feedback mechanisms and students' writing fluency in botswana. International Journal of English Language Teaching, 3(4), 225-232. Retrieved from www.eajournals.org.

Boumediene, H., Berrahal, F. K., \& Harji, M. B. (2017). The effectiveness of portfolio assessment on EFL students' writing performance: the case of third year secondary students in Algeria. Academic Journal of Interdisciplinary Studies, 5(3 S1), 119.

Brewster, J., Ellis, G., \& Girard, D. (2002). The primary English teacher's guide. England: Pearson Education Limited.
Brown, H.D. (2001). Teaching by principles. An interactive approach to language pedagogy. $2^{\text {nd }}$ Ed. New York: Addison Wesley Longman, Inc.

Cahyono, B. Y., \& Widiati, U. (2015). The teaching of EFL vocabulary in the Indonesian context: the state of the art. TEFLIN journal, 19(1), 1-17.

Chou, L. (2011). An investigation of Taiwanese doctoral students' academic writing at a U.S. University. Higher Education Studies, 1(2), 47-60.

Christenson, T.A. (2002). Supporting struggling writers in the elementary classroom. New York: The International Reading Association.

Christopher E.French. (2003). The Effect of the POWER strategy on learning of disables students' writing skill.doi: http://dx.doi.org/10.1207/s15327035ex1201 4.

Cosgun, G. (2016). The impact of using wordlists in the language classroom on students' vocabulary acquisition. International Journal of English Language Teaching, 4(3), 49-66. Retrieved from www. eajournals.org.

Daniel, Panjaitan. (2013). Improving the students' achievement in writing descriptive text through Prepare, Organize, Write, Edit, Rewrite (POWER) Strategy (Unpublished master thesis). Universitas Negeri Medan, Medan.

Dirgeyasa, WY. (2016). The improvement of students' writing skill achievement through error analysis method. International journal of English Language Teaching, 4(3), 1-10. Retrieved from www.eajour nals.org.

Feger, A. L. R., \& Thomas, G. A. (2011). Bailing Out The Once-Ler: Using DR.Seuss To Teach Operations Management. Decision Sciences Journal of Innovative Education, 9(1), 69-73.

Fitria, R. (2015). The Writing Ability of DescriptiveTtext ofTthe Tenth Grade Students of SMA Nu al Ma'ruf Kudus in Academic Year 2014/2015 Taught by Using POWER (Prepare, Organize, Write, Edit, Rewrite) Strategy (Unpublished master thesis). Universitas Muria Kudus, Kudus.

Flores, C. (2015, February). Writing-as-Thinking: The Key to Organizing, Analyzing, and Synthesizing Information. In 2015 AAAS Annual Meeting (12-16 February 2015).

Gillespie, A., Olinghouse, N. G., \& Graham, S. (2013). Fifthgrade students' knowledge about writing process and writing genres. The Elementary School Journal, 113(4), 565-588.

Gregg, L. W., \& Steinberg, E. R. (Eds.). (2016). Cognitive processes in writing. Abingdon: Routledge.

Harmer, J. (2004). How to Teach Writing. England: Pearson Longman. 
Harris, K. R., Graham, S., \& Mason, L. H. (2006). Improving the writing, knowledge, and motivation of struggling young writers: Effects of self-regulated strategy development with and without peer support. American Educational Research Journal, 43(2), 295-340.

Hashempour, Z., Rostampour, M., \& Behjat, F. (2015). The Effect of Brainstorming as a Pre-writing Strategy on EFL Advanced Learners' Writing Ability. Journal of Applied Linguistics and Language Research, 2(1), 86-99.

Hassan, I.O \& Ahamed, H. (2016). The Impact of Instructional Technologies in Teaching English in Sudanese Secondary Schools in Khartoum State. International journal of English Language Teaching, 4(1), 56-63. Retrieved from www.eajournals.org.

Horst, M. (2014). Mainstreaming second language vocabulary acquisition. Canadian Journal of Applied Linguistics/Revue canadienne de linguistique appliquée, 16(1), 171-188.

Jacobs, H.I, Zirgkgaf, S.A, Wormuth, Dr, Horfiel, V.H, Hughey, J.B. (1981). Testing EFL Composition: $A$ practical approach English Composition Program. USA: Newburg House Publisher.Inc.

Karim, R.A.,Abu,A. G., \& Khaja, F. N. M. (2016, November). Brainstorming approach and mind mapping in writing activity. In Proceedings of English Education International Conference, 1( 2), 423-429.

Kenna, J. L. (2017). Geography And Film. Cinematic Social Studies: A Resource for Teaching and Learning Social Studies With Film, 369. P. 375 film can be used in preparation stage.

Khaki, M., \& Biria, R. (2016). Effects of Self-and Peer-Editing on Iranian TEFL Postgraduate Students' L2 Writing. Journal of Applied Linguistics and Language Research, 3(1), 155-166.

Latief, M.A. (2014). Research Methods on Language Learning: An Introduction. Malang: Universitas Negeri Malang Press.

Lavery, C. (2008). Activities for using comics strips. Retrieved from www.teachingenglish.org.

Lesaux, N. K., Kieffer, M. J., Kelley, J. G., \& Harris, J. R. (2014). Effects of academic vocabulary instruction for linguistically diverse adolescents: Evidence from a randomized field trial. American Educational Research Journal, 51(6), 1159-1194.

Li, J. (2016). Modeling the process of summary writing of Chinese learners of English as a foreign language. Irish Educational Studies, 35(1), 73-100.

Limpo, T., \&Alves, R. A. (2013). Modeling writing development: Contribution of transcription and self-regulation to Portuguese students' text generation quality. Journal of Educational Psychology, 105(2), 401.
MacArthur, C. A., Philippakos, Z. A., \& Ianetta, M. (2015). Self-regulated strategy instruction in college developmental writing. Journal of Educational Psychology, 107(3), 855.

Manouchehry, A., Farangi, M.A., Fatemi, M.A., \& Qaviketf, F. (2014). The effect of two brainstorming strategies on the improvement of Iranian intermediate EFL learners writing skill. International journal of language learning and applied linguistics world, 6(4), 176-187.

Maulida, F. (2016). The use of guiding question technique to improve students' descriptive text writing ( $a$ classroom action research at the 7th grade of SMP Muhammadiyah 1 Semarang in the academic year of 2015/2016 (Unpublished master thesis). UIN Walisongo, Semarang.

Mayer, R. E., \& Moreno, R. (2002). Animation as an aid to multimedia learning. Educational psychology review, 14(1), 87-99.

Mohammad, M. F., \& Hussein, A. A. (2013). Enhancing Students Motivation to Write Essays through Brainstorming: A Comparative Study. International Journal of Humanities and Social Science, 3(9), 191196.

Moss, L. (2010). Types of Audio-Visual Materials Used in Teaching. Retrieved from www.ehow.co.uk.

Moussa, I. J. (2015). Reflective Writing through the Use of Guiding Questions. International Journal of Teaching and Learning in Higher Education, 27(1), 104113.

Mujiono, S., Widiati, U., \& Iragiliati, E. (2013). Implementing Leading Question Strategy to Improve the Speaking Skill of the Eleventh Graders SMAN 8 Malang (Unpublished master thesis). Universitas Negeri Malang, Malang.

Ningrum, A. S. B., Latief, M. A., \& Sulistyo, G. H. (2016). The Effect of Mind Mapping on EFL Students' Idea Development in Argumentative Writing across Gender Differences and Learning Styles. Dinamika Ilmu: Jurnal Pendidikan, 16(1), 149-166.

Raimes, A. (1983). Technique in Teaching Writing. New York: Oxford University Press.

Ritonga, M. N. (2015). The Effect Of Guiding Questions Technique On Students achievement In Writing Recount Text (Unpublished master thesis). Universitas Negeri Medan, Medan.

Seidlhofer, B. (2005). English as a lingua franca. ELT Journal, 59(4), 339.

Smith, C.C. (2003). Joining Hands in Writing and Speaking. The internet TESL Journal Vol. IV. The Yale-New Haven Teachers Institute. http:wwww.yale.edu/ ynhti/curriculum units/1986/4/86.04.13.x.html. 
Tayib, A.M. (2016). The Effect Of Using Graphic Organizers On Writing (A Case Study Of Preparatory College Students At Umm-Al-Qura University). International Journal of English Language Teaching, 4(5), 31-53.

Ur, P. (1996). A Course in Language Teaching: Practice and Theory. Cambridge: Cambridge University Press.

Wang, Z. Q. (2014). The Application of Process Writing in Chinese EFL Classrooms in Higher Education. International Journal of English Linguistics, 4(3), 88.

Widiati, U. (2016). Problems with Peer Response of Writingas-a-Process Approach in an EFL Writing Classroom. Jurnal Ilmu Pendidikan, 9(3).
Widiati, U., \& Cahyono, B. Y.(2016). The Teaching of EFL Writing in the Indonesian Context: the State of the Art. Jurnal Ilmu Pendidikan, 13(3).

Wilson, A. (2015). The Effects Of Vocabulary Mastery And Student's Perception On Teaching Material Towards Writing Skill. Deiksis, 7(03), 183-190.

Wulandari, W., Raja, P., \& Hasan, B. (2015). Improving Students'ability In Writing Descriptive Paragraph Trough Guiding Question Technique. U-JET, 4(2).

Yazdi-Amirkhiz, S. Y., Ajideh, P., \& Leitner, G. (2016). The Influence of Collaboration on Individual Writing Quality: The Case of Iranian vs. Malaysian College Students. Journal of English Language Teaching and Learning, 8(17), 1-24. 